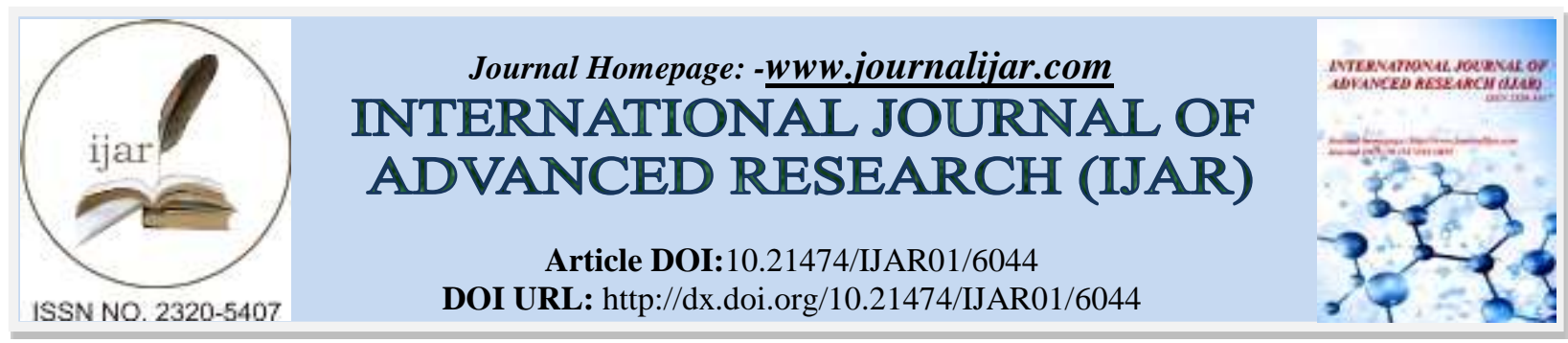

RESEARCH ARTICLE

\title{
ASSESSMENT OF PHYSICO-CHEMICAL PARAMETERS OF KUNIGAL TANK, TUMKUR DIST, INDIA.
}

\section{Lalitha $H M^{1,2}$ and Ramakrishna $S^{1}$.}

1. Department of Zoology, Jnanabharathi campus, Bangalore University, Bengaluru-560056, India.

2. Department of Zoology, University college of Science, Tumkur University, Tumakuru-572103, India.

\section{Manuscript Info}

Manuscript History

Received: 13 October 2017

Final Accepted: 15 November 2017

Published: December 2017

Key words:-

Kunigal tank, pollution, Physicochemical parameters.

\begin{abstract}
Water is one of the naturally occurring vital constituent of the ecosystem which supports all life activities. Fresh water is a source of drinking water and is getting polluted by the discharge of domestic sewage, industrial effluents and anthropogenic activities. Analysis of Physico-Chemical parameters of Kunigal tank, Tumkur district was done during the period of July-2014 to December-2014.The water samples were collected on the monthly basis from five sampling sites. The analysis was carried out for the parameters like Temperature, $\mathrm{pH}$, Electrical conductivity, Turbidity, Chlorides, Nitrates, Sulphates, Phosphates, and Biological Oxygen Demand (BOD).
\end{abstract}

Copy Right, IJAR, 2017,. All rights reserved.

\section{Introduction:-}

Water is one of the most important natural resource needed for the existence and development of life on earth. The aquatic system is disturbed by the contamination of water (1). The water is highly polluted due to the increased human population, industrialization, use of fertilizers and manmade activities (2). The change in the physicochemical properties of water alters the quality of water and affects the aquatic environment and thus causing imbalance in the ecosystem (3). Many health hazards including water borne diseases are linked with the unsafe drinking of water. Therefore, it is essential to check the water quality regularly (4). The present study was carried out to assess the Physico-chemical parameters of Kunigal tank, Tumkur (Dist) India.

Corresponding Author:- Lalitha H M.

Address:-Department of Zoology, Jnanabharathi campus, Bangalore University, Bengaluru-560056, 


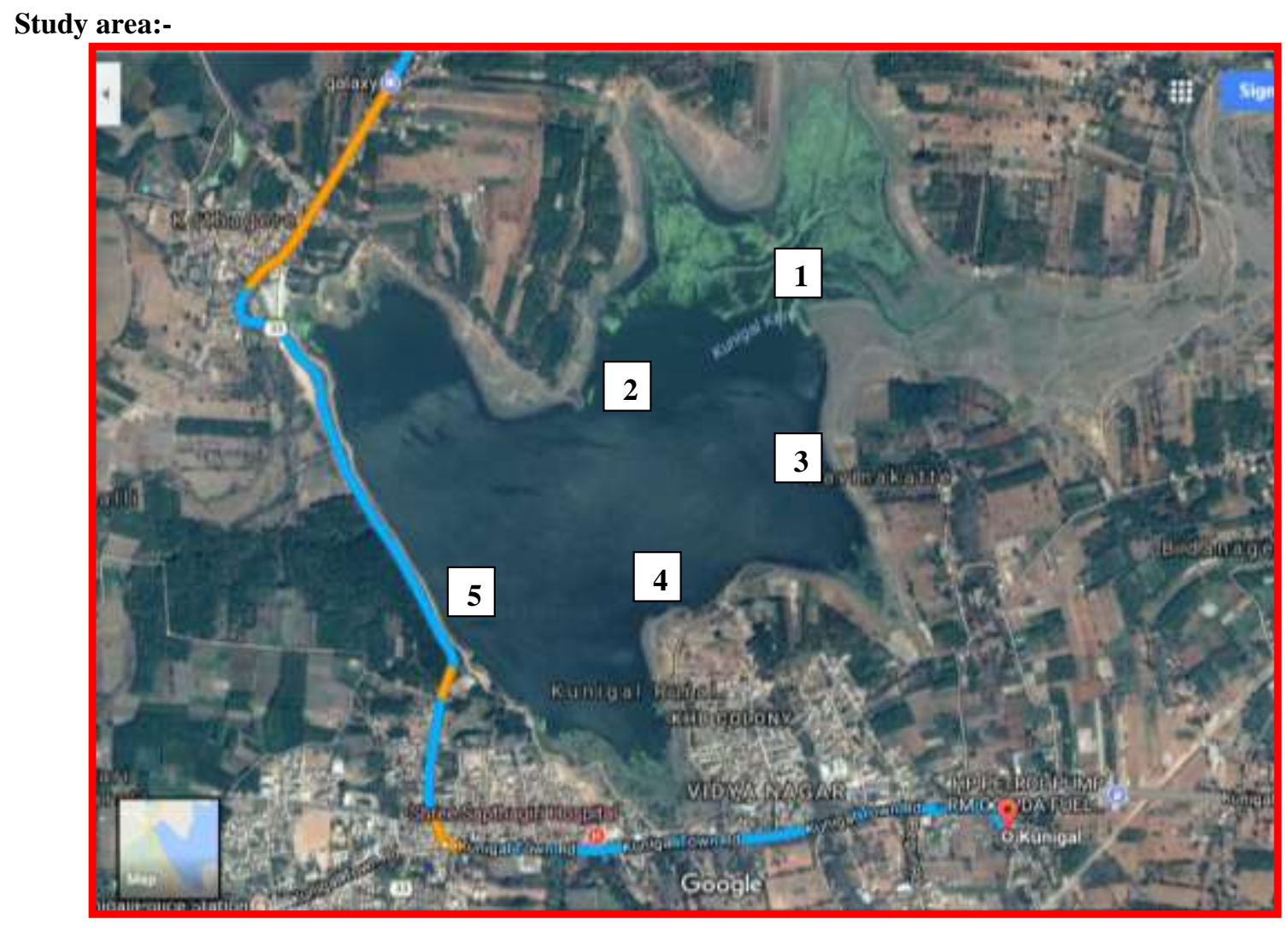

Figure1:- Satellite view of Kunigal Tank and its surroundings.

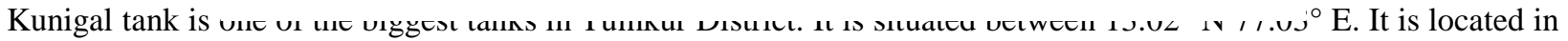
between Kottagere and Kunigal town on Tumkur road as shown in figure 1. The tank is spread across a vast area of 1030 acres of land with a bund of $2 \mathrm{~km}$ long. The catchment area of the tank is 33.914Th ha. The tank was mainly constructed for the purpose of irrigation. Now a days, it is used for various purposes like agriculture, fish culture, drinking and partially for domestic purposes.

\section{Materials and Methods:-}

Surface water samples from Kunigal tank were collected from the selected sampling sites in the morning between 7AM to 9AM in two liters of polythene cans regularly for every month. Five sampling sites were selected which completely cover the whole area of the tank. The sampling locations are shown in Figure 1. The investigation was carried out to study the physico-chemical parameters of water from July- 2014 to December-2014. The temperature was recorded at the spot using Thermometer. In addition to temperature, other physico-chemical parameters such as pH-Electrometric method, Turbidity-Nephelometric method, Electrical conductivity- Electrometric method, Chloride-Argentometric method, Nitrate-Phenol di-sulphonic acid method, Sulphate-Turbidimetric method, Biological Oxygen Demand (BOD) - Winkler's Iodometric method, were estimated for the collected samples in the laboratory using standard methods (5). The results were compared with standard permissible limit by BIS (6).

\section{Results and Discussion:-}

Table 1:- Average values of physico-chemical parameters compared with BIS standards.

\begin{tabular}{|c|c|c|c|c|c|c|c|c|c|}
\hline Month & $\begin{array}{c}\text { Temp. } \\
\left({ }^{\circ} \mathrm{C}\right)\end{array}$ & $\mathrm{pH}$ & $\begin{array}{c}\text { Turbidity } \\
\text { NTU }\end{array}$ & $\begin{array}{c}\text { Electrical } \\
\text { conductivity } \\
\mu \mathrm{s} / \mathrm{cm}\end{array}$ & $\begin{array}{c}\text { Chloride } \\
\mathrm{mg} / \mathrm{L}\end{array}$ & $\begin{array}{c}\text { Sulphate } \\
\mathrm{mg} / \mathrm{L}\end{array}$ & $\begin{array}{c}\text { Phosphate } \\
\mathrm{mg} / \mathrm{L}\end{array}$ & $\begin{array}{c}\text { Nitrate } \\
\mathrm{mg} / \mathrm{L}\end{array}$ & $\begin{array}{c}\text { BOD } \\
\mathrm{mg} / \mathrm{L}\end{array}$ \\
\hline $\begin{array}{c}\text { BIS } \\
\text { Standards }\end{array}$ & 40 & $6.5-8.5$ & 5 & - & 250 & 200 & - & 45 & 5 \\
\hline July-2014 & 25.9 & 7.4 & 2.9 & 203 & 24 & 11 & 0.9 & 0.54 & 4 \\
\hline
\end{tabular}




\begin{tabular}{|l|c|c|c|c|c|c|c|c|c|}
\hline $\begin{array}{l}\text { Aug- } \\
2014\end{array}$ & 26.2 & 7.2 & 2.8 & 180 & 22 & 2 & 0.89 & 0.44 & 7 \\
\hline Sep-2014 & 26.1 & 7.4 & 2.7 & 176 & 22 & 2 & 0.92 & 0.32 & 10 \\
\hline Oct-2014 & 27.1 & 7.4 & 3.4 & 179 & 25 & 2 & 0.83 & 0.31 & 15 \\
\hline $\begin{array}{l}\text { Nov- } \\
2014\end{array}$ & 26.3 & 7.4 & 3.6 & 180 & 26 & 3 & 0.94 & 0.34 & 9 \\
\hline Dec-2014 & 25.1 & 8.6 & 2.7 & 194 & 20 & 2 & 0.91 & 0.35 & 4 \\
\hline
\end{tabular}

Table-1 shows the range of physico-chemical parameters compared with the BIS standards to know the water quality of the tank.

\section{Temperature:-}

Temperature is one of the important parameter which affects the various activities of the aquatic organisms like respiration, metabolism etc. It depends on the environmental factors like rainfall, humidity, weather, wind etc. The rate of all chemical reactions is regulated by the water temperature which in turn affects the growth and reproduction of fishes (9). In the study period, water temperature ranged from $25.1^{\circ} \mathrm{C}$ to $27.1{ }^{\circ} \mathrm{C}$. The maximum water temperature $\left(27.1^{\circ} \mathrm{C}\right)$ was recorded in October-2014 and minimum water temperature $\left(25.1^{\circ} \mathrm{C}\right)$ was recorded during December-2014.

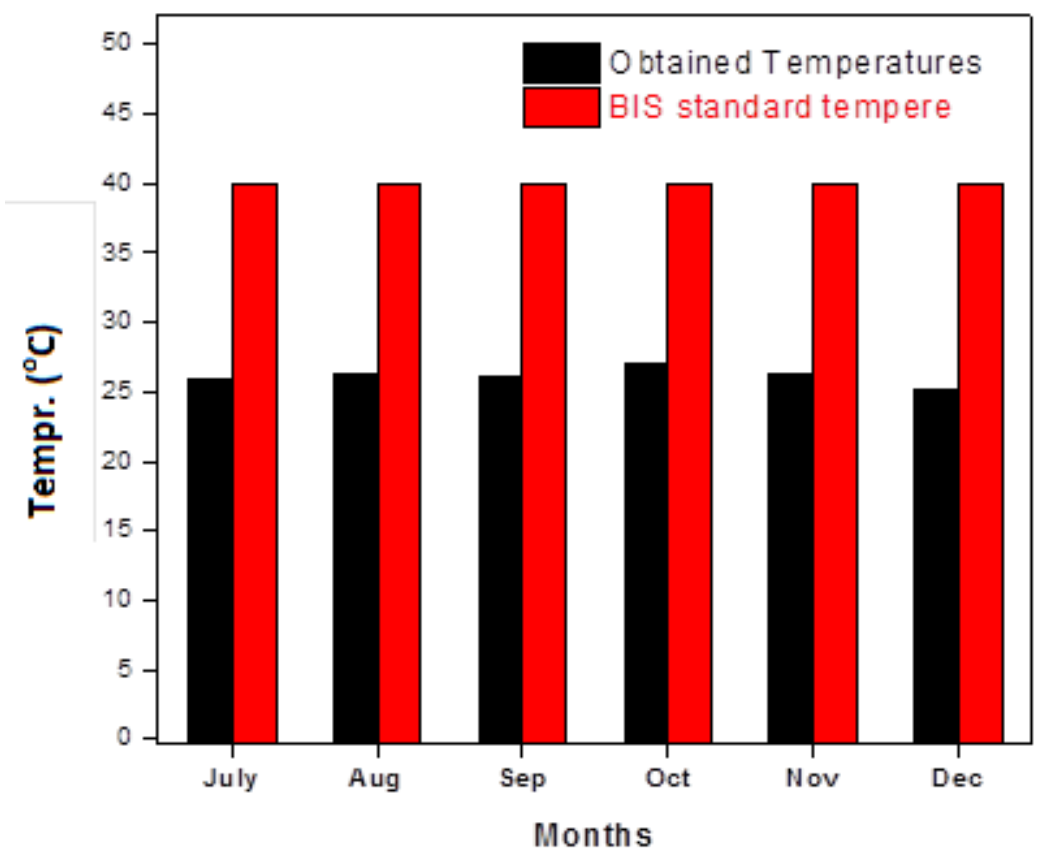

Figure 2:- Comparison of Temperature values with BIS standards

\section{Turbidity:-}

In a water sample, turbidity measures the amount of light scattered by the particles. Ihe colloidal solution is formed by the aggregation of suspended particles. The extremely minute particles occupy the surface bottom and minute particles remain as suspended which forms turbidity. Turbidity of water ranges from 2.7 to $3.6 \mathrm{NTU}$. The highest value of 3.6NTU was observed in November-2014 and lowest value of 2.7 NTU was observed in September and December- 2014. 


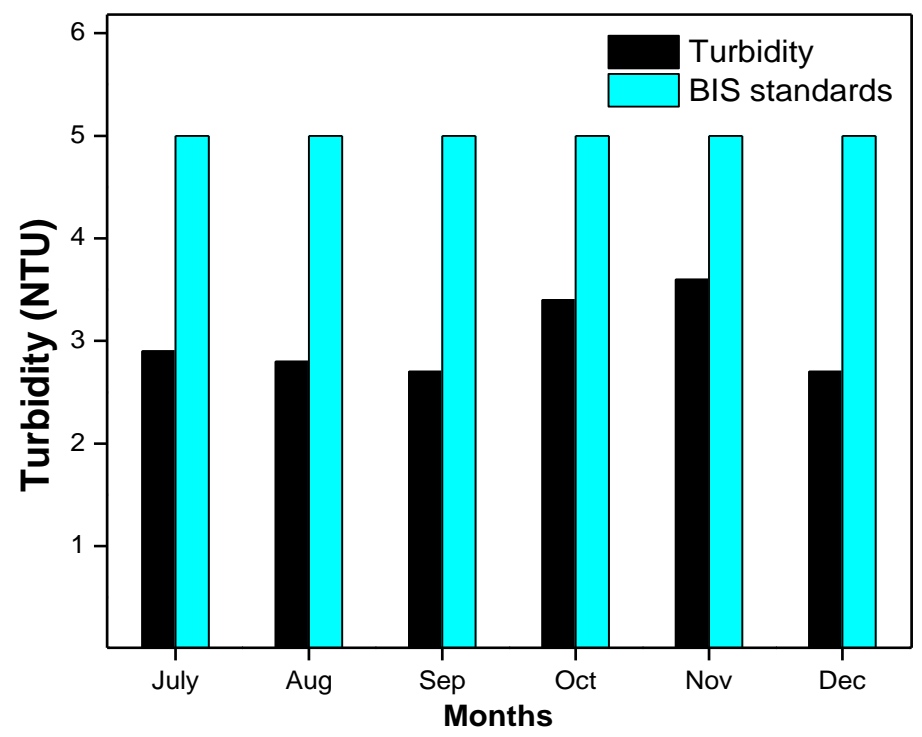

Figure 3:- Comparison of Turbidity values with BIS standards

pH:-

$\mathrm{pH}$ is defined as the inte

It is one of the important physico-chemical factors for estimating the water quality. The acidic and alkaline nature of water is determined by the $\mathrm{pH}$. The $\mathrm{pH}$ of water is regulated by carbon dioxide and bicarbonates. It is affected by the factors like Temperature, salinity.

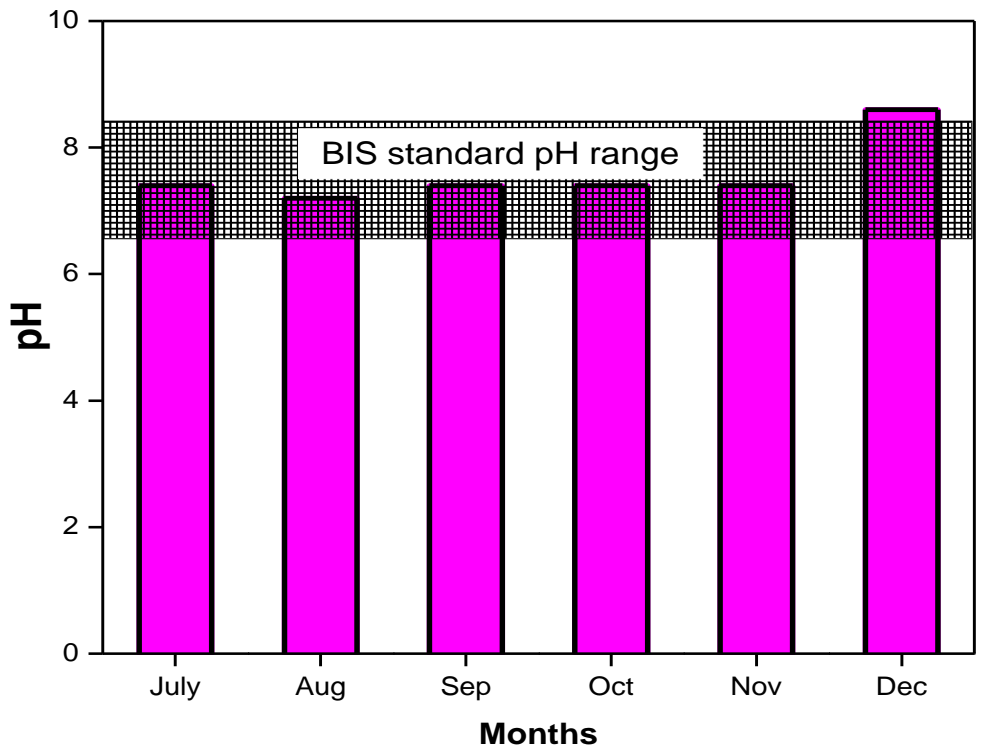

Figure 4:- Comparison of $\mathrm{pH}$ values with BIS standards

In the current study the $\mathrm{pH}$ was alkaline and found in the range between 7.2to 8.6. The maximum value of $\mathrm{pH}(7.2)$ was recorded in August-2014 and minimum value of $\mathrm{pH}$ (8.6) was recorded in December-2014. 


\section{Electrical conductivity:-}

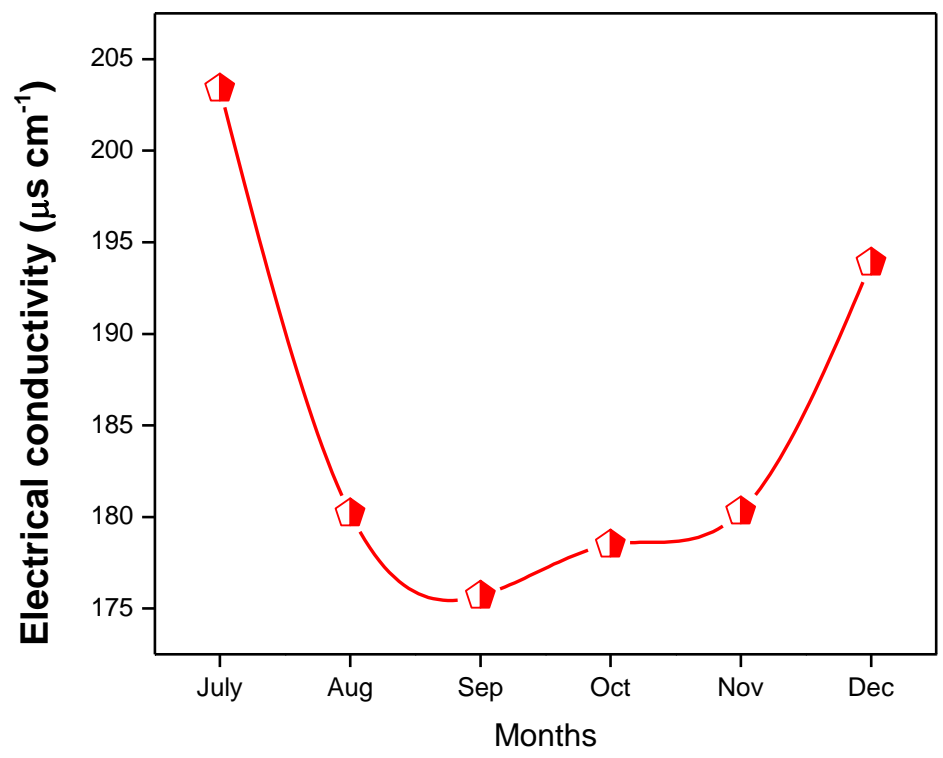

Figure 5:- Electrical conductivityof water samples

Electrical conductivity (EC) is the ability of aqueous solution to carry electrical current. It depends on the presence of ions,their concentrations and temperature. The increase in EC of water indicates the degree of pollution. The water quality can be checked by controlling the conductivity of water. The Electrical conductivity in the present study was ranged from $176 \mathrm{mg} / \mathrm{L}$ to $203 \mathrm{mg} / \mathrm{L}$. The maximum value of EC (203 mg/L) was recorded in July-2014 and minimum value of EC (176 mg/L) was recorded in September-2014.

\section{Sulphates:-}

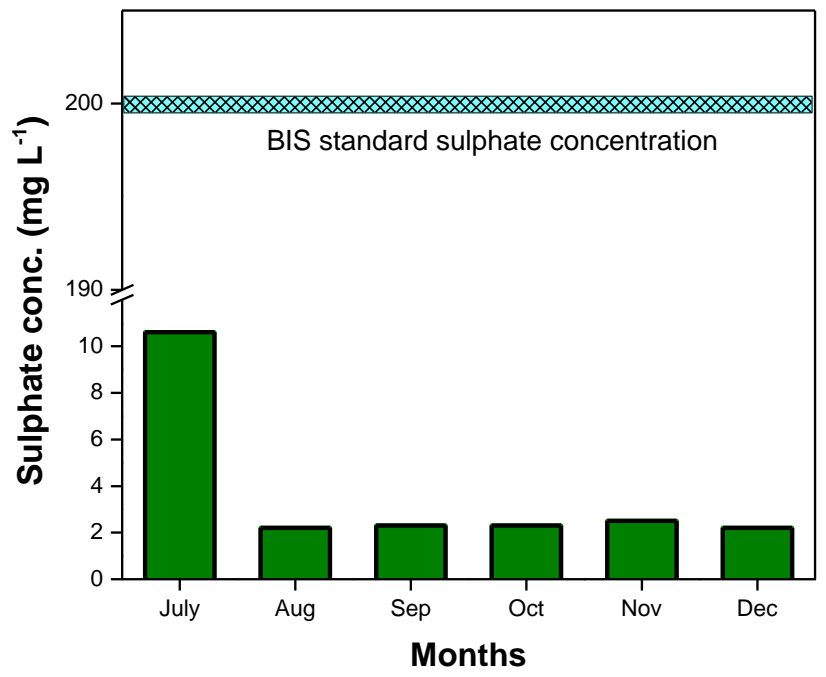

Figure 6:- Comparison of Sulphate values with BIS standards

Sulphur is added to water through runoff water containing fertilizers, organic and mineral sulphur compounds and by the dissolution of minerals from soil and rocks. High amount of sulphate induces bitter taste to water. The values 
of Sulphates in the present study ranged from $2 \mathrm{mg} / \mathrm{L}$ to $11 \mathrm{mg} / \mathrm{L}$. The maximum value $(11 \mathrm{mg} / \mathrm{L})$ was recorded in July-2014 and minimum value ( $2 \mathrm{mg} / \mathrm{L}$ ) was recorded in August- 2014 and December-2014.

\section{Phosphates:-}

Phosphate is a fundamental element in the metabolic reactions of plants and animals. It is essentially found in bones and teeth. It controls the growth of algae and primary productivity. The increased phosphates in water leads to eutrophication and results in the excessive algal growth called Algal bloom.

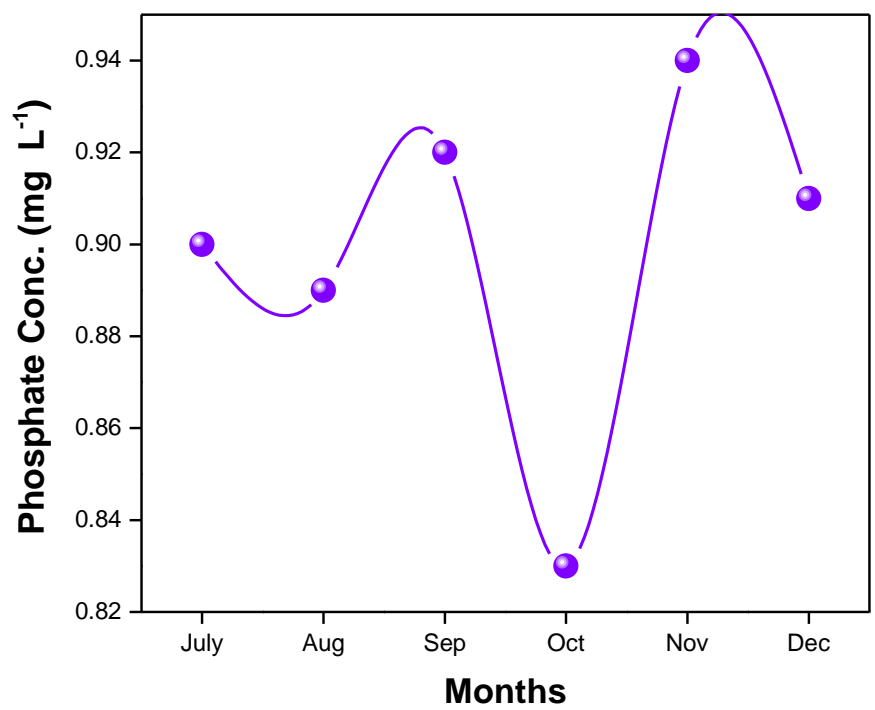

Figure 7:- Comparison of Phosphate values with BIS standards

The values of Phosphates fluctuate from $0.83 \mathrm{mg} / \mathrm{L}$ to $0.94 \mathrm{mg} / \mathrm{L}$. Maximum value of Phosphates $(0.94 \mathrm{mg} / \mathrm{L})$ was recorded in November-2014 and minimum value of Phosphates $(0.83 \mathrm{mg} / \mathrm{L})$ was recorded in October-2014.

\section{Chlorides:-}

Chlorides play a very important role in determining the quality of water. The chloride concentration is higher in organic wastes. The higher chloride concentration indicates the increased level of water pollution from the organic wastes (8).

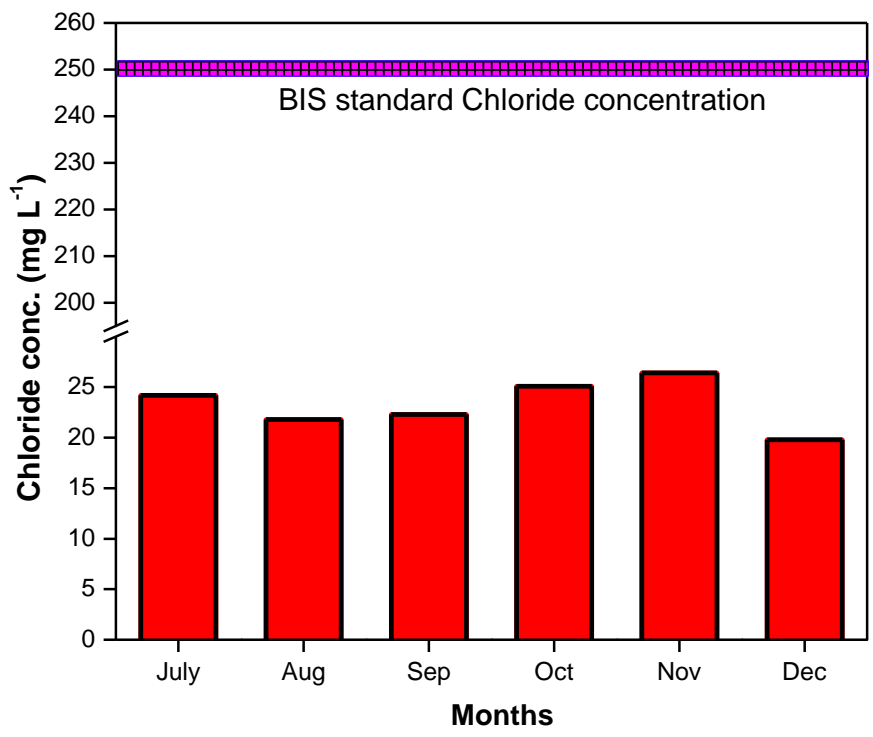

Figure 8:- Comparison of Chloride values with BIS standards 
The values of Chlorides fluctuate from $20 \mathrm{mg} / \mathrm{L}$ to $26 \mathrm{mg} / \mathrm{L}$. Maximum value of Chlorides (26 mg/L) was recorded in November-2014 and minimum value of Chlorides $(20 \mathrm{mg} / \mathrm{L})$ was recorded in December-2014.

\section{Nitrates:-}

Nitrate is a very good parameter to decide the organic pollution of water and indicate the highest oxidized form of nitrogen (7). In the present study, the values of Nitrates ranged from $0.31 \mathrm{mg} / \mathrm{L}$ to $0.54 \mathrm{mg} / \mathrm{L}$.

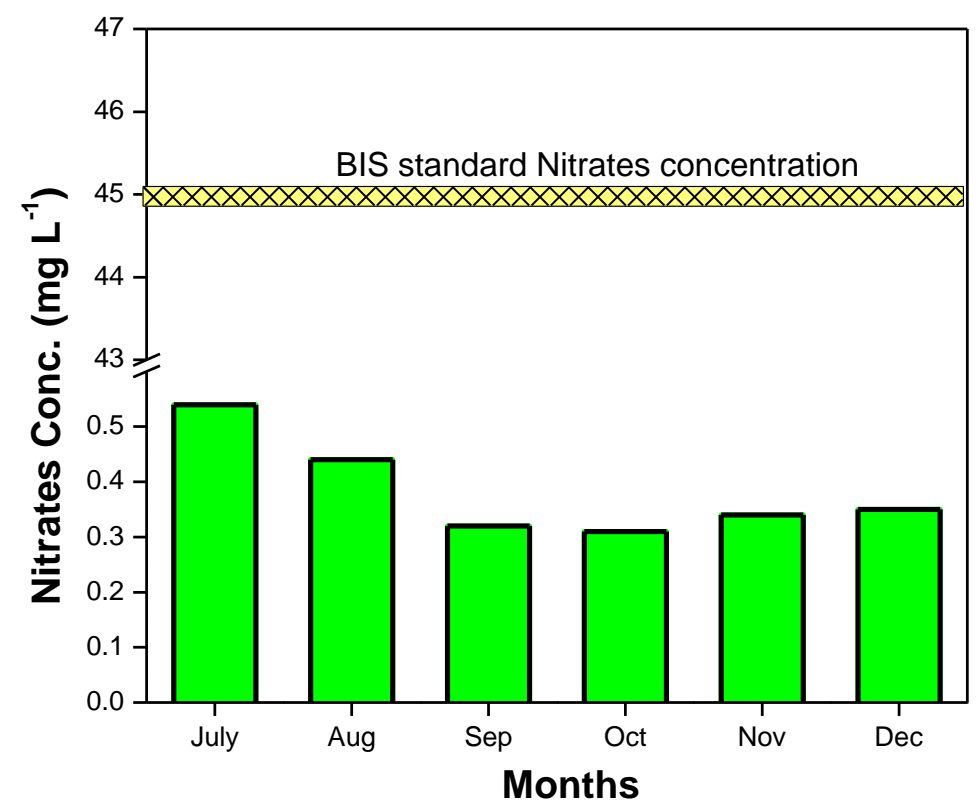

Figure 9:- Comparison of Nitrate values with BIS standards

The maximum value of Nitrates $(0.54 \mathrm{mg} / \mathrm{L})$ was observed in July-2014 and minimum value of Nitrates $(0.31 \mathrm{mg} / \mathrm{L})$ was observed in October-2014.

\section{BOD:-}

BOD is the amount of dissolved oxygen required for the biochemical degradation of organic matter. It indicates the magnitude of water pollution by oxidizable organic matter.

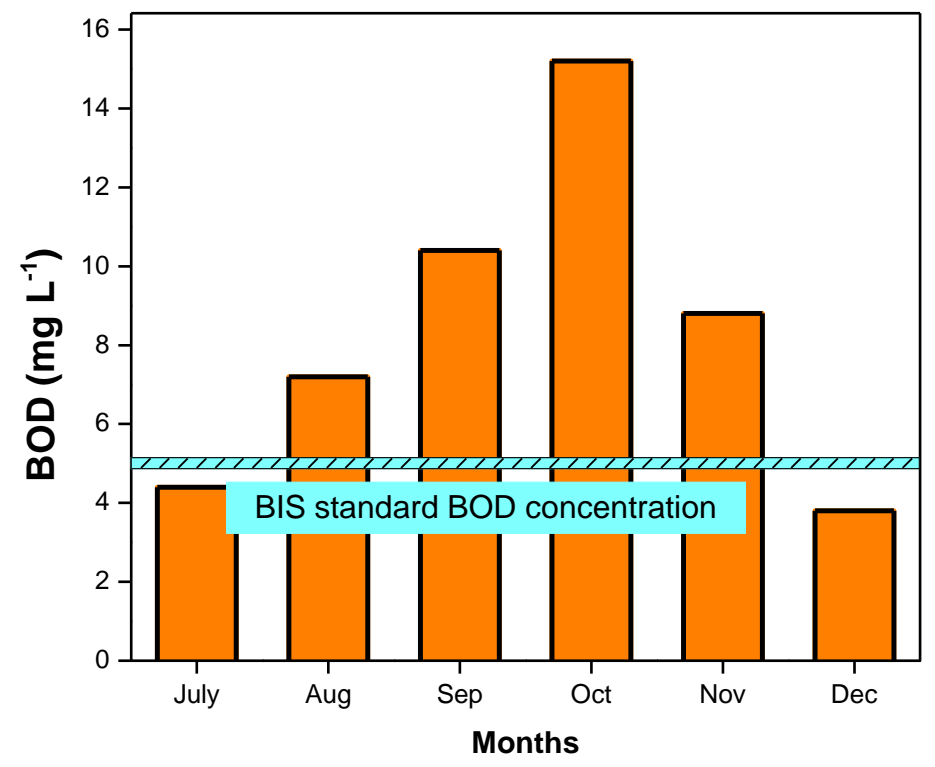

Figure 10:- Comparison of BOD values with BIS standards 
The main sources of organic pollution are domestic sewage, agricultural runoff and industrial effluents. The values of BOD ranges from $4 \mathrm{mg} / \mathrm{L}$ to $15 \mathrm{mg} / \mathrm{L}$. The maximum value of BOD $(15 \mathrm{mg} / \mathrm{L})$ was found in September-2014 and the minimum value of BOD (4 mg/L) was found in December -2014 .

\section{Conclusion:-}

From the present study, it is concluded that $\mathrm{pH}$, Temperature, Turbidity, Electrical conductivity, Sulphate, Phosphate, Chloride and Nitrate are within the Permissible limits of BIS standard except BOD which was beyond the permissible limit. During the study period, in the month of August, September, October and November- 2014, the BOD was recorded beyond the permissible limit. This may be due to the reduction in the level of water and increased human activities in the tank. Hence, the water can be used for agriculture and in this period, the tank water is used for drinking purpose only after the treatment.

\section{References:-}

1. Biradar, N.V., Ambarish, S, and Sindagi. (2014): Assessment of Physico-chemical and Microbiological parameters of Kotur Lake, Dharwad, Karnataka, India. Research Journal of Recent sciences., 3: 57-62.

2. Bureau of Indian Standard (BIS). (2004): Specification for drinking water, Indian Standard Institution, (Bureau of Indian Standard), New Delhi. 10500

3. Harney, N.V., Dhamani A.A., and Andrew R.J. (2013): Seasonal Variations in the Physico- chemical parameters of Pindavani Pond of Central India. Weekly Science. 1, 1-8.

4. Manjare, S.A., and Vhanalakar S. A. (2010): Analysis of Water Quality Using Physico- Chemical parameters Tamdalge Tank in Kolhapur District, Maharashtra, International Journal of Advanced Biotechnology And Research., 1: 115-119.

5. Mallikarjunaswamy, G.C., and Hina kousar., (2015): Studies on hydrological parameters of Tiptur lake, Tumkur district, Karnataka state, India. International Journal of Research Studies in Biosciences., 3: 29-34.

6. Munawar, M. (1970): Limnological studies on fresh water ponds of Hyderabad, India. J. Hydrobiologia. 35: 127-162.

7. Patil, P. N., Sawant, D.V., and Deshmukh R.N. (2012): Physico-chemical parameters for testing of water- A review. International journal of Environmental sciences. 3: 1194-1207.

8. Shylaja, M. B., and Hinakouser., (2015): Estimation of Hardness in Municipal Tap Water of some Selected Areas of Tiptur Town, Tumkur District. International Journal of Research Studies in Biosciences., 3: 127-133.

9. Standard methods for the examination of water and waste water. (1998): American Public Health Association, American water works Association, Water Environment Federation, Washington, D.C. 